\title{
Governance Reform Committee Invites Comments
}

T he Ad Hoc Committee on Governance Reform invites comments from all APSA members on its proposed agenda. Comments received by October 1, 2014 will guide the committee in its deliberations at a retreat now planned for December 2014. A revised Constitution or set of Bylaws will be proposed by summer 2015 .

\section{BACKGROUND}

The APSA presently operates under a Constitution and Bylaw which are sometimes inconsistent with one another, and neither complies fully with federal and District of Columbia regulations governing nonprofit organizations. At the very least, we need to revise our governing documents to resolve these inconsistencies. In addition, before he retired, Michael Brintnall submitted a memo to the APSA Governing Council reflecting on lessons he had learned and problems of governance he had encountered as Executive Director. This thoughtful memo prompted APSA President Jane Mansbridge to ask the APSA Rules Committee to propose a procedure for addressing questions of governance reform.

The Rules Committee suggested the following steps, which were approved by the APSA Council at its August 2013 meeting:

Appoint ad hoc committee for approval by the Council (Fall 2013)

Ad hoc committee drafts an agenda for reform for retreat (see below) (Spring 2014)

Proposed agenda discussed by the APSA Council at Spring meeting (Spring 2014)

Draft agenda posted on APSA website for open comment by membership (Spring/ Summer 2014)

Two day Retreat by Ad Hoc Committee on Governance, with perhaps additional invited guests (December 2014)

Propose changes to the Constitution and preliminary report to the APSA Council (Spring 2015)

Proposed changes posted on the APSA website for open comment by membership (Spring/Summer 2015)
Second draft of proposed changes and report to the APSA Council (September 2015)

Final draft of proposed changes (Fall/Winter 2016)

Approval by APSA Council (Spring 2016)

Vote by membership at annual meeting or electronic ballot (September 2016)

Pursuant to the approval of this procedure, APSA President John Aldrich proposed and the Administrative Committee of the Council approved the following members of the Governance Reform Committee (step 1):

David A. Lake, University of California, San Diego (Chair)

Jeffrey Berry, Tufts University

Terri Givens, University of Texas

Kerstin Hamann, University of Central Florida

Jonathan Koppell, Arizona State University

Ashley Leeds, Rice University

Joanne Miller, University of Minnesota

Jeffrey Segal, Stony Brook University

Dara Strolovitch, Princeton University

The Committee then drafted an agenda for reform (step 2) that was submitted to the Governing Council, which approved this proposal agenda at its April 2014 meeting (step 3). This agenda is now open for comments from the APSA membership (step 4). The Ad hoc committee on Governance Reform currently plans a retreat in December to develop proposals for submission to the APSA council next Spring (step 5).

\section{PROPOSED AGENDA FOR GOVER- \\ NANCE REFORM}

\section{Purpose and Nature of the Associa-} tion

What is the appropriate decision-making balance between membership bodies and APSA headquarters and staff? What responsibilities can and should be delegated to headquarters and which must be retained or overseen by the membership bodies?

\section{Basic Constitutional Structure of APSA}

What should be the principal governance bodies within the association? At present, governance occurs within the Annual Business Meeting, Governing Council (GC), and Administrative Committee. Are these the right bodies? Do they stand in relation to one another in appropriate ways?

What should be the rights, responsibilities, and duties of each governance unit?

What is the appropriate mechanism for codifying the governance structure and processes of the association? At the moment, the association has a Constitution and Bylaws that include a mix of very specific instructions and general powers. Should we have one set of Bylaws (subject to approval of the membership) that includes everything or minimalist Bylaws (subject to approval of the membership) and a policy manual (subject to approval only by the GC)?

\section{Composition of the GC}

What is the appropriate size and composition of the GC (Constitution limits current $\mathrm{GC}$ to 16 members)?

What are the appropriate terms of service for GC members (Currently two years)?

How should the members of the GC be selected and approved?

Who should the GC represent and how can this representation be best ensured? Should the GC include "stakeholders" inside and outside the association who are not now represented (e.g., the TLC, departments, organized sections, foundations and public officials)? Should some current stakeholders, such as the editors of journals, be represented on the GC by some other mechanism (e.g., a publications committee chair)?

How can GC members be best brought "up to speed" on issues before the association and retain some institutional memory?

\section{Committee structure and specificity}

What is the appropriate committee structure for the association?

To whom should the committees report and be responsible?

What rights, responsibilities and duties should each committee have? 
Coming in the NEXT ISSUE

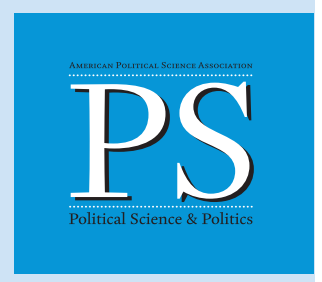

A preview of some of the articles in the October 2014 issue:

\section{SYMPOSIUM}

Forecasting the 2014 Midterm Elections, James E. Campbell, guest editor

\section{FEATURES}

Has the Tea Party Era Radicalized the GOP? Evidence from Text Analysis of the 2008 and 2012 Republican Primary Debates, Juraj Medzihorsky, Levente Littvay, and Erin K. Jenne

Colleague Crowdsourcing: A Method for Incentivizing National Student Engagement and Large-N Data Collection, Amber E. Boydstun and Jessica T. Feezell

\section{THE PROFESSION}

Social Science Literacy in Undergraduate Political Science Education: The Current State of Affairs, an Agenda of Action, and Proposed Fundamental Benchmarks, Kim Quaile Hill and Rebekah Myers

Navigating the International Academic Job Market, Nilay Saiya

\section{THE TEACHER}

Secondary Students and the Deliberation of Public Issues, Patricia Grant Avery, Sara A. Levy, and Annette M. M. Simmons

High-Impact Political Science Internships in a "Low-Density Opportunity" Environment, Brian Anderson

Satire and Efficacy in the Political Science Classroom, Rebecca A. Glazier

Teaching Canadian Politics and Foreign Policy On-Site: Benefits and Challenges, James M. McCormick

\section{ASSOCIATION NEWS}

2014 Annual Meeting Highlights
What is the relationship between standing committees of the association and ad hoc committees that may be formed?

How should committee members be selected and approved?

\section{Procedures of the GG}

How frequently should the GC meet? (Currently twice per year)

\section{Officers}

How should officers of the association be selected and approved?

What are the appropriate terms of service for officers? VPs and Secretary are currently one year. Should they serve ex officio as "incoming" officers or in some other capacity?
Comments on these agenda items and proposals for additional items to be taken up by the committee are welcome. Please submit your comments to the committee before October 1, 2014, via e-mail to govreform@apsanet.org.

The APSA membership will have subsequent opportunities to comment on the specific proposals for reform that emerge from the retreat and other deliberations (step 7). The final set of reforms will be submitted to the membership for approval in September 2016 (step 11).

\section{Briefs}

\section{Calls for Papers}

\section{CES CONFERENCE IN PARIS}

The 22nd International Conference of Europeanists will take place from July 8-10, 2015 in Paris, France. The 2015 CES conference will focus on the theme of "Contradictions: Envisioning European Futures." And, the Council invites proposals for papers, panels and mini-symposia. The submission period opens on August 15, 2014 and closes October 10, 2014. Robert Fishman of the University of Michigan and Jenny Andersson of Sciences Po will co-chair the 2015 Conference Program Committee, while CES board member Virginie Guiraudon will head the Local Organizing Committee. For more info, visit our 2015 conference page.

\section{MIDWEST POLITICAL SCIENCE ASSOCIATION 2015 CONFERENCE}

Deadline for submitting complete panel proposals is September 26, 2014.

Deadline for submitting paper and roundtable proposals: October 3, 2014

Visit http://www.mpsanet.org/Conference/MPSA2015Conference/ImportantDeadlines/tabid/816/Default.aspx

\section{SOUTHERN POLITICAL SCIENCE ASSOCIATION 2015 CONFERENCE}

Call for proposals deadline is August 1 , 2014. Visit www.spsa.net for details.

\section{Reviewers Needed!}

Most of $P S$ readers have never been asked to review. If you are interested in this opportunity,we encourage you to contact us at ps@ apsanet.org, and we will help you update your information in our database, alert the editor to your willingness to review, and involve you in this review process. If you have not reviewed before, read "How To Be a Peer Reviewer: A Guide for Recent and Soon to be PhDs" by Beth Miller, John Pevehouse, Ron Rogowksi, Dustin Tingley, and Rick Wilson in PS 46 (1): 120-23. This article "includes why reviewing is important to the development of one's own scholarship but includes some nuts and bolts on reviewing." See also the Cambridge University Journal page for author and peer reviewers, alike, for responsibilities of both authors and reviewers. Visit http://journals.cambridge.org/action/ stream ?pageId $=6728 \&$ level $=2$ 